\title{
Spatial and temporal distribution of gerrid (Heteroptera) and predation on microcrustaceans from a tropical shallow lake
}

\author{
A. R. Domingos ${ }^{a *}$ and M. S. Arcifa ${ }^{a}$ \\ ${ }^{a}$ Laboratório de Limnologia, Departamento de Biologia, Faculdade de Filosofia, Ciências e Letras de Ribeirão Preto - \\ FFCLRP, Universidade de São Paulo - USP, Av. Bandeirantes, 3900, CEP 14040-901, Ribeirão Preto, SP, Brazil \\ *e-mail: andresrdomingos@usp.br
}

Received: August 14, 2015 - Accepted: August 3, 2016 - Distributed: May 31, 2017

(With 3 figures)

\begin{abstract}
Predator-prey interactions involving an aquatic insect and zooplanktonic prey of different sizes were investigated to quantify prey mortality exposed to predators. Laboratory experiments were undertaken with the young and adult gerrid Rheumatobates crassifemur to test predation and size selectivity on the cladocerans Daphnia gessneri, Ceriodaphnia richardi, and Bosmina tubicen. Population fluctuations and spatial distribution of the gerrid were also evaluated in a small and shallow Brazilian lake throughout 12 months in fortnightly samples. The insects were more abundant in the littoral (mean density $7.0 \pm 1.2$ ind. $\mathrm{m}^{-2}$ ) compared to the limnetic zone. The period with the highest densities was late January to June, in both zones. Predation by young instars on Daphnia and Ceriodaphnia was significant (mean ingestion rate of $1.3 \pm 0.1$ D. gessneri and $0.7 \pm 0.1$ C. richardi per predator per hour). Adult insect fed only the large-sized prey (mean ingestion rate of $1.0 \pm 0.1 \mathrm{D}$. gessneri per predator per hour). Young gerrids have greater potential to prey on cladocerans than adults, and size selectivity occurred for both predators. Preference of adults by the larger prey is probably related to difficulties in manipulating smaller planktonic prey, such as Ceriodaphnia. Due to higher densities of insects in the littoral, higher predation on zooplankton in this zone is expected. This study does contribute to a better understanding of trophic interactions in tropical shallow lakes and is the first to investigate predation of a gerrid on cladocerans in laboratory experiments.
\end{abstract}

Keywords: predation, gerrids, aquatic insects, zooplankton, neotropical lake.

\section{Distribuição espacial e temporal de gerrídeo (Heteroptera) e a predação sobre microcrustáceos de um lago tropical raso}

\section{Resumo}

Foram investigadas as interações predador-presa, envolvendo inseto aquático e presas zooplanctônicas de diferentes tamanhos para quantificar a mortalidade das presas expostas a predadores. Experimentos de laboratório foram realizados com jovens e adultos do gerrídeo Rheumatobates crassifemur para testar a predação e a seletividade por tamanho das espécies de cladóceros Daphnia gessneri, Ceriodaphnia richardi e Bosmina tubicen. Flutuações populacionais e a distribuição espacial do gerrídeo também foram avaliadas em um lago brasileiro pequeno e raso durante 12 meses em amostras quinzenais. Os insetos foram mais abundantes no litoral (densidade média 7,0 $\pm 1,2$ ind. $\mathrm{m}^{-2}$ ) em comparação com a zona limnética. Maiores densidades ocorreram de fim de janeiro a junho, em ambas as zonas. A predação dos jovens foi significativa sobre Daphnia e Ceriodaphnia (taxa de ingestão média 1,3 $\pm 0,1 \mathrm{D}$. gessneri and $0,7 \pm 0,1 \mathrm{C}$. richardi por predador por hora). Adultos predaram somente a presa maior (taxa de ingestão média 1,0 $\pm 0,1 \mathrm{D}$. gessneri por predador por hora). Gerrídeos jovens têm um maior potencial para predar cladóceros que os adultos, e seletividade por tamanho ocorreu para ambos. A preferência dos adultos somente pela presa maior provavelmente está relacionada à dificuldade em manipular pequenas presas planctônicas como Ceriodaphnia. Devido às maiores densidades de insetos no litoral, é esperada maior predação sobre o zooplâncton nesta zona. Este estudo contribui para uma melhor compreensão sobre interações tróficas em lagos tropicais rasos e é o primeiro a investigar a predação de um gerrídeo sobre cladóceros em experimentos de laboratório.

Palavras-chave: predação, gerrídeos, insetos aquáticos, zooplâncton, lago neotropical. 


\section{Introduction}

Historically, the influence of invertebrate predators on lentic ecosystems has received less attention than vertebrate predators, but many studies have shown that they are important agents in structuring biological communities of lentic ecosystems (Hall et al., 1970; Zaret, 1980; Kerfoot and Sih, 1987; Arner et al., 1998). The impact and selectivity of a predator on prey communities of lentic ecosystems depend on many factors, as the joint effect of species of predators present in the environment (Hanazato and Yasuno, 1989), prey size (Brooks and Dodson, 1965; Brooks, 1968; Hall et al., 1976), population density, duration of predation pressure (Eitam and Blaustein, 2010), foraging behavior, and prey defenses (Peckarsky, 1982). However, based on empirical and theoretical studies, it seems that the body size of both predators and prey is one of the most important factor determining the role of species in the community (Warren and Lawton, 1987; Cohen et al., 1993; Woodward and Hildrew, 2002; Woodward et al., 2005). Several authors observed that aquatic heteropterans exhibit a tendency to select prey by size, with preference for the largest ones, resulting in density reduction of larger species, without affecting smaller ones (Cooper, 1983; Scott and Murdoch, 1983; Murdoch and Scott, 1984; Gilbert and Burns, 1999; Gergs and Ratte, 2009).

Aquatic insects are a diverse group of animals present in most water bodies. Diving beetles, waterbugs, chaoborid and dragonfly larvae are usually the top predators in fishless lakes and thus may greatly affect the structure and dynamics of food webs. Predation by invertebrates on zooplankton communities has been studied in Lake Monte Alegre, a tropical shallow lake in southeastern Brazil. Chaoboridae larvae is one of the main invertebrate predators (Arcifa et al., 1992, 2015; Arcifa, 2000; Castilho-Noll and Arcifa, 2007a, b), whose impact is stronger during the warm season (Arcifa et al., 1992, 2015). Water mites (Cassano et al., 2002) and notonectids (Domingos and Arcifa, In press) also prey on cladocerans. However, little is known on potential predation of gerrids on zooplankton community. Moreover, because they are very abundant in the studied lake, a question emerged whether they can prey on microcrustaceans and consequently influence the structure of the zooplankton community in shallow tropical lakes, since this is the first study so far.

The family Gerridae (Heteroptera), whose species are popularly known as water striders, is the most diverse animal group associated with the water surface. These insects usually inhabit small streams to large rivers, ponds and lakes, and even the ocean. They are highly adapted to live over the water surface with regard to activities, such as locomotion, feeding, mating behavior, and for completing their life history (Andersen, 1982; Spence and Anderson, 1994). Differences can be found in the timing of gerrids life cycle, which apparently separated the peaks of abundance and microhabitat preference of several species (Cheng, 1966; Jamieson, 1973). A few species inhabit a wide variety of aquatic environments, but most species show a degree of habitat preference, such as the vegetation near the margins of ponds and lakes, flowing waters, and the open ocean or near coasts in areas fringed with mangrove (Vepsäläinen, 1973; Calabrese, 1977; Spence and Scudder, 1980; Cheng, 1985). For species associated with the littoral vegetation of freshwaters, younger instars tend to occupy areas with dense vegetation, whereas the largest individuals are usually found in areas with lower vegetation abundance (Nummelin et al., 1984; Wheelwright and Wilkinson, 1985). Gerrids are a predaceous group and seem to be generalist feeders (Cummins, 1973; Peckarsky, 1982). They feed mainly on terrestrial arthropods that fall on the film of water surface tension and on aquatic invertebrates that maintain some degree of contact with the water surface (McLean, 1990). They can also feed on planktonic crustaceans, such as copepods, and fish larvae (Cheng, 1974). Cannibalism is common in this group, and probably is a response to crowding and food shortage (Nummelin et al., 1984; Nummelin, 1989).

Since most studies on invertebrate predation was carried out in temperate lakes, new insight on tropical lakes may be of great interest to know the potential role of predation in the structuring of prey communities. This is specially applied to gerrids, since predation of this group on planktonic species is little known in both tropical and temperate lakes. Therefore, this study contributes to a better understanding on the ecology of gerrids and their potential predation on cladocerans.

Our aim was to determine in laboratory experiments if juveniles and adults of the gerrid Rheumatobates crassifemur Esaki prey on three different sized planktonic cladoceran species by size selective predation and if there is difference of ingestion rate between young and adult predators. Prey are the large-sized Daphnia gessneri $(\sim 1.2 \mathrm{~mm})$, medium-sized Ceriodaphnia richardi $(\sim 0.6 \mathrm{~mm})$, and small-sized Bosmina tubicen $(\sim 0.4 \mathrm{~mm})$. We also evaluated spatial and temporal distribution of gerrids in the lake, because by knowing the zones of the lake and the periods of the year when population densities are higher, we can infer the local and time period when the potential predation would be greater. Our hypotheses were: I. the gerrid can prey on planktonic organisms, juveniles being more effective predators than adults; II. both juvenile and adult are size selective predators and ingest more individuals of the larger cladoceran than of the smaller ones; III. the gerrid population is more abundant in the littoral zone; IV. the species densities are related to water temperature, wind, and rainfall.

\section{Materials and Methods}

\subsection{Study site}

Lake Monte Alegre is located in southeastern Brazil, in the town of Ribeirão Preto-SP, inside the campus of the

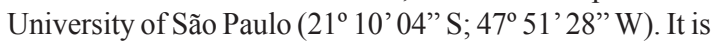
a small, shallow, tropical eutrophic reservoir (area $=7$ ha; maximum depth $=5 \mathrm{~m}$; altitude $500 \mathrm{~m}$ a.s.1.) (Figure 1). The reservoir was created in 1942 from damming the 


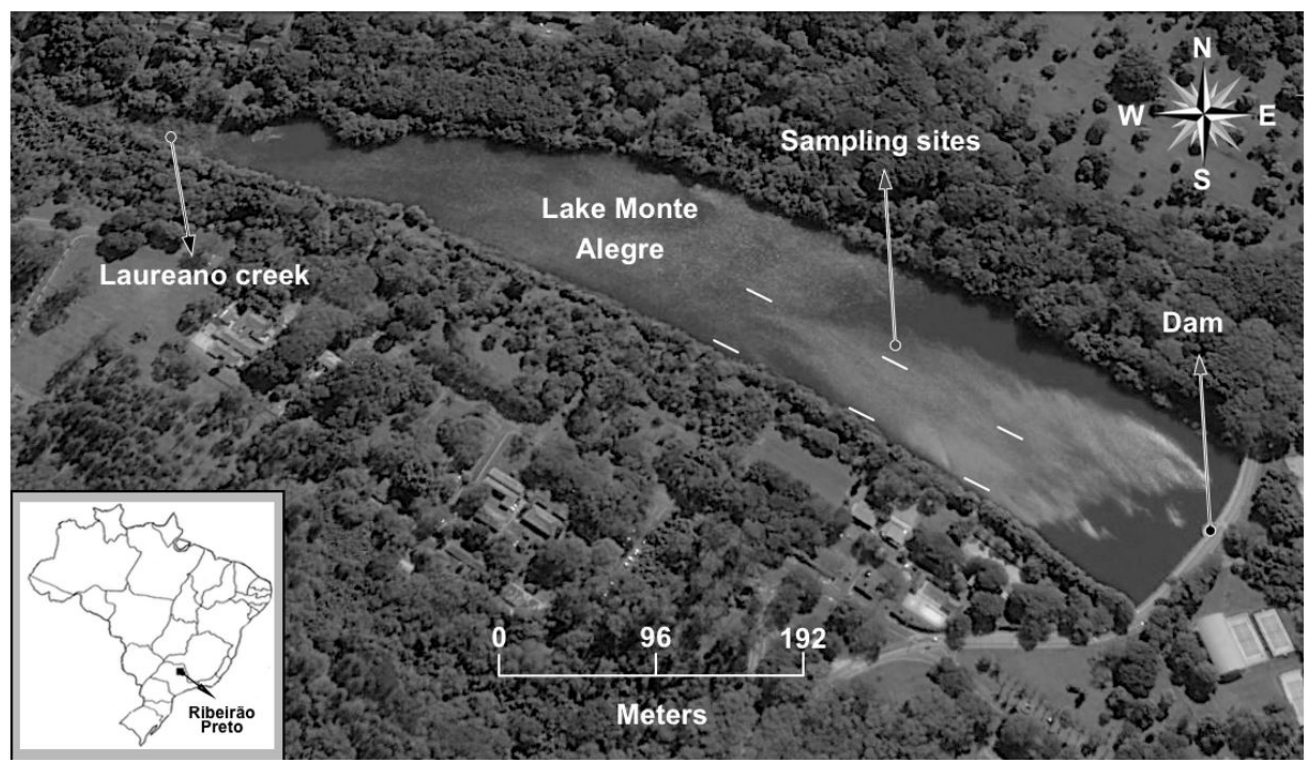

Figure 1. Map of Lake Monte Alegre. The sampling sites are transects of $10 \mathrm{~m}$ ( 3 in the littoral and 3 in the limnetic zone).

Laureano Creek, which belongs to the Pardo River basin. Its functioning is similar to a natural lake due to the lack of dam manipulation and a residence time $(\sim 45 \mathrm{~d})$ relatively high for its dimensions. The margins and surroundings are covered by trees, and the aquatic vegetation is predominantly composed of the emergent macrophyte Ludwigia sp., distributed in narrow stands along most of the southwestern littoral of the lake. The climate of the region is Tropical, with two well-defined seasons: warm-wet (October-April) and cool-dry season (May-September) (Arcifa et al., 1990). The only filter-feeder planktivorous fish is the adult of the exotic cichlid Tilapia rendalli Boulenger, which is not abundant (Arcifa and Meschiatti, 1993). The main invertebrate predators are the dipteran Chaoborus brasiliensis Theobald (Castilho-Noll and Arcifa, 2007a), the water mite Krendowskia sp. (Cassano et al., 2002), and the backswimmer Martarega uruguayensis Berg (Domingos and Arcifa, In press).

\subsection{Field sampling}

The fluctuations and spatial distribution of $R$. crassifemur were analyzed in fortnightly samplings, from December 2011 to December 2012. Superficial water temperature was measured by a probe (Yellow Springs ${ }^{\mathrm{TM}^{\circledR}}$ Model 95) on each sampling event. Measurements of rainfall and wind velocity were obtained at a meteorological station (Center for Integrated Agrometeorological Information) located approximately $5 \mathrm{~km}$ from the lake. The gerrids were collected in the littoral zone, near the edge of macrophytes ( $1 \mathrm{~m}$ deep, with stands of the macrophyte Ludwigia sp.) and in the limnetic zone ( $5 \mathrm{~m}$ deep without macrophytes). We used a boat to perform superficial sweepings with a dip net $(0.37 \times 0.28 \mathrm{~m} ; 500 \mu \mathrm{m}$-mesh $)$ in 3 longitudinal transects in each zone, $10 \mathrm{~m}$ long each (Figure 1). We tried to maintain a distance of $100 \mathrm{~m}$ among the transects in order to reduce spatial and temporal autocorrelation among replicates. Insects were preserved in ethanol $80 \%$ and individuals were counted to calculate the population density in each date. Insects were measured under the stereomicroscope to identify instars and their relative abundance in the population. The cladocerans used as prey in the experiments were collected with a plankton net $(60 \mu \mathrm{m}$-mesh) by three vertical hauls. They were cultivated at the laboratory to obtain a sufficient number of individuals for the experiments.

\subsection{Laboratory experiments}

Five experimental assays were performed following the described conditions and procedures (Table 1). Insects were kept in an environmental chamber (FANEM ${ }^{\mathrm{TM}}{ }^{\circledR}$, model CDG), at $25^{\circ} \mathrm{C}$ and diffuse light, in $80 \mathrm{~mL}$ beakers filled with filtered lake water (glass fiber, Millipore ${ }^{\mathrm{TM}}{ }^{\circledR}$ AP20 -0.8 to $8.0 \mu \mathrm{m}$ ). The predators were deprived of food for $24 \mathrm{~h}$ prior to the experiments, for standardizing their level of hunger. The culture of zooplankton was carried out in glass bottles attached to a plankton wheel, with addition of $1 \mathrm{mg} \mathrm{C} \mathrm{L}^{-1}$ of the chlorophycean Desmodesmus spinosus Chodat (former Scenedesmus spinosus) every other day until they reach maturity (4-7 days). After the acclimation time of gerrids, feeding trials were made to analyze the consumption of the cladocerans by young (mean size $1.80 \pm 0.03 \mathrm{~mm}$ ) and adult gerrids (mean size $2.99 \pm 0.03 \mathrm{~mm}$ ). In each experiment, only one species of prey was used.

Two treatments were set, with six replicates each: 1. predator + prey $(\mathrm{P}+)$; and 2. control with prey only $(\mathrm{P}-)$. Each replicate contained 20 adult prey as Initial Density (ID) and 2 predators in $(\mathrm{P}+)$ treatment, according to Scott and Murdoch (1983) and Cassano et al. (2002). Before the beginning of the experiments, prey were randomly caught 
Table 1. Experimental conditions and the length (mean \pm SD) of species: Prey - Bosmina tubicen; Ceriodaphnia richardi and Daphnia gessneri; Predator - Rheumatobates crassifemur.

\begin{tabular}{|c|c|c|}
\hline \multicolumn{3}{|c|}{ Experimental conditions } \\
\hline Acclimation time & & 24 hours \\
\hline Temperature & & $25^{\circ} \mathrm{C}$ \\
\hline Containers & & $1800 \mathrm{~mL}$ beakers \\
\hline $\mathrm{N}^{0}$ of replicates & & 6 replicates \\
\hline $\mathrm{N}^{0}$ of predators & & 2 predators per replicate \\
\hline Initial Density (ID) & & 20 prey per replicate \\
\hline \multirow[t]{2}{*}{ Experimental time } & & 2 hours \\
\hline & Prey and length (mm) & Predator and length $(\mathrm{mm})$ \\
\hline \multirow[t]{2}{*}{ Experiment 1} & D. gessneri & R. crassifemur \\
\hline & $1.11 \pm 0.17$ & $2.97 \pm 0.08$ (adult) $\hat{\jmath} \bigcirc$ \\
\hline \multirow[t]{2}{*}{ Experiment 2} & C. richardi & R. crassifemur \\
\hline & $0.64 \pm 0.01$ & $3.01 \pm 0.06$ (adult) $\hat{\jmath} 0$ \\
\hline \multirow[t]{2}{*}{ Experiment 3} & D. gessneri & R. crassifemur \\
\hline & $1.22 \pm 0.11$ & $1.80 \pm 0.10$ (juvenile $)$ \\
\hline \multirow[t]{2}{*}{ Experiment 4} & C. richardi & R. crassifemur \\
\hline & $0.65 \pm 0.01$ & $1.84 \pm 0.10$ (juvenile) \\
\hline \multirow[t]{2}{*}{ Experiment 5} & B. tubicen & R. crassifemur \\
\hline & $0.44 \pm 0.01$ & $1.78 \pm 0.08$ (juvenile) \\
\hline
\end{tabular}

from the bottles without distinction between ovigerous and non-ovigerous females, and were placed in $1800 \mathrm{~mL}$ beakers ( $15 \mathrm{~cm}$ in diameter) filled with $500 \mathrm{~mL}(5 \mathrm{~cm}$ high) of filtered lake water (glass fiber, Millipore ${ }^{\mathrm{TM}}{ }^{\circledR} \mathrm{AP} 20-0.8$ to $8.0 \mu \mathrm{m}$ ). Then, $1 \mathrm{mg} \mathrm{C} \mathrm{L}^{-1}$ of $D$. spinosus was added to the beakers as food for microcrustaceans. Replicates were arranged in the chamber in a systematic way to avoid pseudoreplication. After $2 \mathrm{~h}$, predators were removed from the beakers and the following variables were evaluated: Intact Prey (IP), Natural Prey Death (NPD), Experimental Error (EE) and Ingestion Rate (IR). IP represents individuals that were alive and NPD the individuals that died without influence of predators. These individuals are easily recognizable since damages were not perceptible in their bodies, such as crushed carapace or holes, and the internal parts were intact. EE was calculated only for the treatments (P-), and is the mean error in counting prey after the experiment ends, since the number of individuals in (P-) should be the same at the beginning and the end of the experiment; it was calculated by the Initial Density (ID) minus Intact Prey (IP) in the control treatment (P-). The estimated IR of prey eaten per predator per hour was calculated following Gilbert and Burns (1999):

$$
I R=I P c-I P e / T \times N
$$

where (IPc) is the Intact Prey in the control treatment (P-), (IPe) is the Intact Prey in the treatment with predators $(\mathrm{P}+)$, (T) is time in hours and $(\mathrm{N})$ is the number of predators in the treatments.

\subsection{Statistical analyses}

In order to find out possible interactions between the fluctuations of the gerrid population and abiotic factors, a Pearson correlation test $(p \leq 0.05)$ was used to analyze the relationships between the densities of gerrids and the factors: water temperature, wind, and rainfall. The mean densities of gerrids in the zones (littoral and limnetic) and seasons (warm-wet and cool-dry) were compared by the non-parametric Mann-Whitney test. Kruskal Wallis and Dunnett's C tests were used to compare the mean relative abundance of instars (I to VI) during the whole period. The dispersion index $\left(\mathrm{DI}=\sigma^{2} / \mu\right)$, where $\sigma^{2}$ is the variance and $\mu$ is the mean, was applied to infer aggregation of gerrids in the environment in each zone and sampling date. The index was used to test the null hypothesis that the observed distribution pattern is random. The DI with $\mathrm{n}-1$ degrees of freedom is approximately distributed as $\chi^{2}$, small values meaning random distribution whereas large values $(\geq 5.99 ; p \leq 0.05)$ indicate aggregation (Bailey, 1987).

Mann-Whitney test was used to compare IP and NPD between the treatments $(\mathrm{P}+)$ and $(\mathrm{P}-)$, and Kruskal-Wallis to compare EE between experiments (1 to 5). Since the parametric test assumptions were filled (Shapiro-Wilk and Levene tests $p<0.05$ ), two-way analysis of variance (ANOVA) was applied to test the effect of different developmental stages of the predators (juvenile and adult) and different species of cladoceran prey (Ceriodaphnia richardi and Daphnia gessneri) on IR of the gerrids. The programs Statistica ${ }^{\text {TM }}{ }^{\circledR} 8.0$ and IBM $^{\circledR}$ SPSS $^{\circledR}$ Statistics were used to perform all statistical analyses using the significance level of $95 \%$.

\section{Results}

\subsection{Laboratory experiments}

At the end of the experiments we counted the number of intact prey (IP), naturally dead prey (NPD), and calculated the experimental error (EE) and ingestion rate 
(IR) (Table 2). Statistical differences of the means of IP between the treatments were found for the experiment 1 (D. gessneri vs. adult; Mann-Whitney, $n=6, U=0.0, p=0.00$ ), experiment 3 (D. gessneri vs. juvenile; Mann-Whitney, $n=6, U=0.0, p=0.00)$, experiment 4 (C. richardi vs. juvenile; Mann-Whitney, $n=6, U=0.5, p=0.00$ ) and experiment 5 (B. tubicen vs. juvenile; Mann-Whitney, $n=6, U=0.0, p=0.00)$. However, the experiments with $B$. tubicen were performed only once, since this species agglomerated at the water surface of the beakers. Thus, independently of the presence of predator in the beakers, prey would die due to the impossibility to dive back into the water column. Thus, we decided not to use that species in further experiments due to misinterpretation of the results. The other two prey species did not show this behavior and dispersed in the water column, moving in search of food, including in the layer just below the film of surface tension of the water.

It was observed the effect of the instar (adult and juvenile) on IR of predators (ANOVA two-way F 1, $20=16.18, p=0.00$ ), juveniles consuming more prey than adults (Figure 2). The effect of prey species (large-sized $D$. gessneri and medium-sized $C$. richardi) on the IR was also different (ANOVA two-way F 1, $20=36.40, p=0.00$ ), $D$. gessneri being more consumed than $C$. richardi. Juveniles significantly preyed on both cladocerans, but fed more on $D$. gessneri than on $C$. richardi, whereas adults preyed only on D. gessneri (Figure 2).

Natural death of cladocerans (NPD) occurred in almost all replicates (Table 2). These individuals showed no evidence of predatory attack, and did not represent a problem in estimating IP, since they were easily recognized because of their conspicuous milky appearance and the intact structures. There was no difference in the mean NPD between the treatments, except for the experiment 3 (D. gessneri vs. juvenile; Mann Whitney, $n=6, U=1.00$, $p=0.00)$ and the experiment 5 (B. tubicen vs. juvenile; Mann Whitney, $n=6, U=6.00, p=0.04$ ). However, for the experiment 3 the mean NPD was higher in the treatment $(\mathrm{P}+)$, while in the experiment 5 it was higher in the treatment (P-). Thus, in the experiment 3, there was a likely influence of the predator on NPD of $D$. gessneri, because the mean was higher in the treatment $(\mathrm{P}+)$. On the other hand, in experiment 5, NPD was higher in the treatment (P-) because of the agglomeration of $B$. tubicen at the water surface, leading to death of the individuals

Table 2. Mean ( \pm SE) values of the variables (EE) experimental error (ind/replicate), (NPD) natural prey death (ind/replicate), (IP) intact prey (ind/replicate) and (IR) ingestion rate (prey pred..$\left.^{-1} \mathrm{~h}^{-1}\right)$ in the treatment $(\mathrm{P}+)$ containing predator and prey and in the treatment $(\mathrm{P}-)$ containing only prey.

\begin{tabular}{|c|c|c|c|c|c|c|c|c|}
\hline \multirow{2}{*}{ Experiment } & \multirow{2}{*}{ Instar } & \multirow{2}{*}{ Prey } & \multirow{2}{*}{$\begin{array}{c}\text { EE } \\
\text { P- }\end{array}$} & \multicolumn{2}{|c|}{ NPD } & \multicolumn{2}{|c|}{ IP } & \multirow{2}{*}{$\begin{array}{l}\text { IR } \\
\text { P+ }\end{array}$} \\
\hline & & & & P- & $\mathbf{P}+$ & P- & $\mathbf{P}+$ & \\
\hline 1 & Adult & Daphnia & $0.0 \pm 0.0$ & $0.3 \pm 0.2$ & $0.5 \pm 0.2$ & $20.0 \pm 0.0$ & $16.5 \pm 0.6$ & $1.0 \pm 0.1$ \\
\hline 2 & Adult & Ceriodaphnia & $0.5 \pm 0.3$ & $0.8 \pm 0.4$ & $1.5 \pm 0.2$ & $19.5 \pm 0.3$ & $19.5 \pm 0.2$ & $0.0 \pm 0.1$ \\
\hline 3 & Juvenile & Daphnia & $0.0 \pm 0.0$ & $0.1 \pm 0.1$ & $2.0 \pm 0.3$ & $20.0 \pm 0.0$ & $15.0 \pm 0.3$ & $1.3 \pm 0.1$ \\
\hline 4 & Juvenile & Ceriodaphnia & $0.2 \pm 0.1$ & $0.7 \pm 0.3$ & $0.7 \pm 0.2$ & $19.8 \pm 0.1$ & $17.0 \pm 0.6$ & $0.7 \pm 0.1$ \\
\hline 5 & Juvenile & Bosmina & $0.7 \pm 0.2$ & $1.3 \pm 0.4$ & $0.3 \pm 0.2$ & $19.3 \pm 0.2$ & $5.5 \pm 1.0$ & $3.5 \pm 0.4$ \\
\hline
\end{tabular}

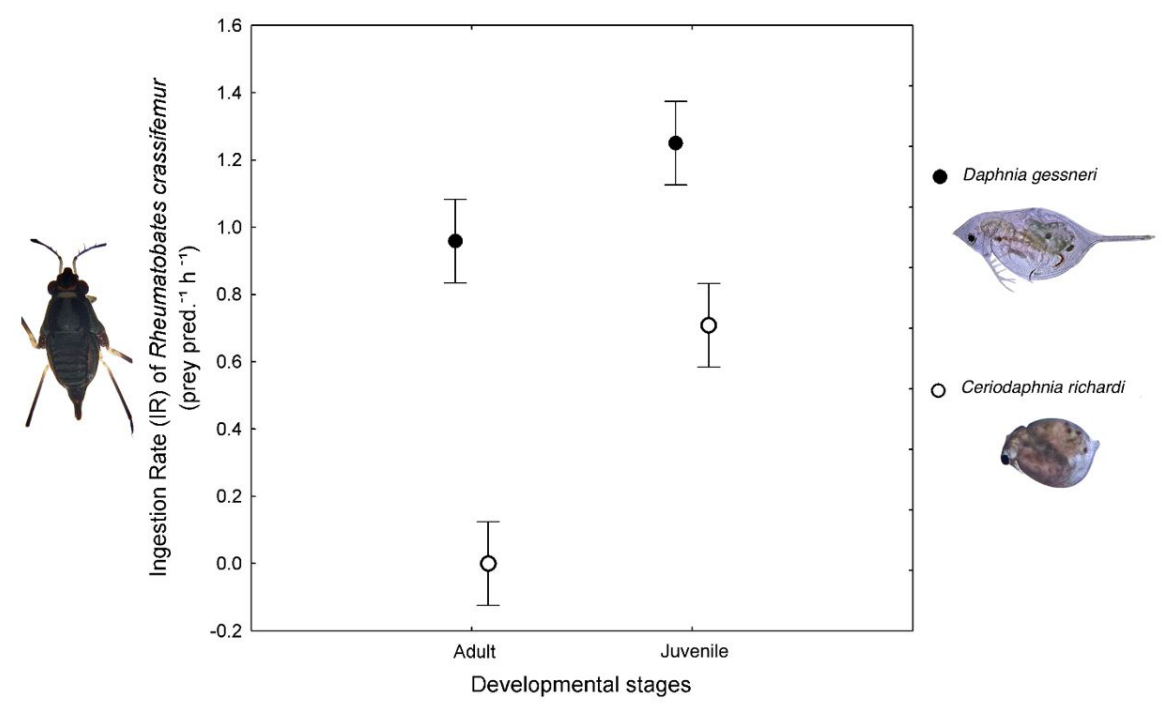

Figure 2. Ingestion rate (IR) (mean $\pm \mathrm{SE}$ ) of the cladocerans Daphnia gessneri and Ceriodaphnia richardi by young and adult Rheumatobates crassifemur. 
without predation. However, in the treatment $(\mathrm{P}+)$ of the experiment 3 , the individuals trapped at the surface were preyed on. Thus, the influence of natural death in the experiments was negligible, so the effect of predators, which eventually could cause an imperceptible injury that would culminate in the prey death, was not detected in our experiments, except for experiment 3. Experimental error (EE) was null in $76.7 \%$ of the replicates of the control treatments, and no statistical difference was observed among all the five experiments performed, meaning that there was no interference of count error on the experimental results (Table 2).

\subsection{Abiotic factors, fluctuations, spatial distribution and age structure}

Lower values of rainfall and maximum wind velocity were recorded in the cool season, but mean wind velocity was higher in the warm season (Table 3 ). The densities of gerrids were not significantly correlated with temperature, wind velocity or rainfall. There was no difference between the mean density of the insects in the cool $\left(6.9 \pm 1.5\right.$ ind. $\left.\mathrm{m}^{-2}\right)$ and warm $\left(9.2 \pm 2.3\right.$ ind. $\left.\mathrm{m}^{-2}\right)$ seasons (Mann Whitney, $n=26, U=39.00, p=0.61)$.

There was a significant higher mean density of the insects in the littoral $\left(7.0 \pm 1.2\right.$ ind. $\left.\mathrm{m}^{-2}\right)$ compared with the limnetic zone $\left(1.3 \pm 0.4\right.$ ind. $\left.\mathrm{m}^{-2}\right)$ (Mann Whitney, $n=26, U=73.0, p=0.00)$. Higher densities were recorded between late January to June, for both littoral and limnetic zones (Figure 3).

There were significant differences in the abundance of the instars (Kruskal Wallis, $n=26, H=16.51, p=0.00$ ), ranked in the following order: instar II $>$ adult $=$ instar I $>$ instars III $=$ IV $=$ V (Table 4).

In the littoral zone, gerrids were mostly aggregated, especially when high density was recorded, and randomly distributed when density was low. Dispersion index (DI) in the littoral zone ranged from 0.5 to 61.3 . In the limnetic zone, random distribution was observed in most samplings and DI ranged from 0.0 to 21.8 .

Table 3. Minimum, maximum and mean $( \pm \mathrm{SD})$ values of water temperature in the lake, wind velocity, and rainfall.

\begin{tabular}{lrrrrrrrr}
\hline & \multicolumn{3}{c}{ Warm-wet season } & & \multicolumn{3}{c}{ Cool-dry season } \\
\cline { 2 - 4 } & Minimum & Maximum & Mean & & Minimum & Maximum & Mean \\
\hline Water temperature $\left({ }^{\circ} \mathbf{C}\right)$ & 26.1 & 30.7 & $28.8 \pm 1.3$ & & 22.3 & 26.1 & $23.7 \pm 1.2$ \\
Wind velocity $(\mathbf{m} / \mathbf{s})$ & 5.3 & 11.1 & $8.2 \pm 1.5$ & & 4.5 & 16.0 & $7.8 \pm 3.2$ \\
Rainfall $(\mathbf{m m})$ & 0.0 & 30.5 & $4.2 \pm 8.7$ & & 0.0 & 19.1 & $1.8 \pm 5.7$ \\
\hline
\end{tabular}

Table 4. Mean density $( \pm \mathrm{SE})$ of the instars I to VI during the study period.

\begin{tabular}{cccc}
\hline Instar & $\boldsymbol{n}$ & Density (ind.m $\mathbf{~}^{\mathbf{2}}$ ) & Post-Hoc \\
\hline I & 26 & $1.8 \pm 0.5$ & $\mathrm{~B}$ \\
II & 26 & $2.7 \pm 0.6$ & $\mathrm{~A}$ \\
III & 26 & $0.8 \pm 0.2$ & $\mathrm{C}$ \\
IV & 26 & $0.5 \pm 0.1$ & $\mathrm{C}$ \\
V & 26 & $0.4 \pm 0.1$ & $\mathrm{C}$ \\
VI (Adult) & 26 & $2.0 \pm 0.7$ & $\mathrm{~B}$ \\
\hline
\end{tabular}

Comparisons were made by Kruskal Wallis and Dunnett's C tests $(p<0.05)$. Same letters mean there is no statistical difference.

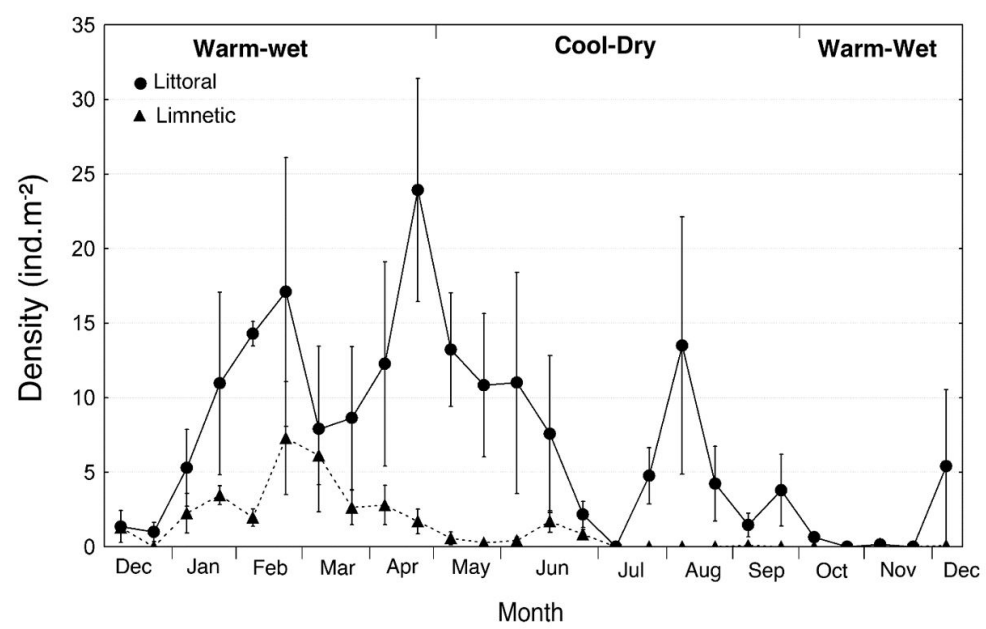

Figure 3. Density (mean $\pm \mathrm{SE}$ ) of Rheumatobates crassifemur in the littoral and limnetic zones, during 12 months and fortnightly samplings. 


\section{Discussion}

Our results confirm the hypothesis that the gerrid $R$. crassifemur preys on cladocerans, and that juveniles are more effective predators than adults. Other studies also report higher predation pressure by young instars of heteropterans on Daphnia and Ceriodaphnia, in comparison to adults (Scott and Murdoch, 1983; Murdoch and Scott, 1984; Murdoch et al., 1984; Domingos and Arcifa, In press). Accordingly, in our study, young instars were more effective predators than adults. Empirical data generally show that the larger the predator, the larger the prey it consumes (Claessen et al., 2000). Due to the fact that adult gerrid consumes only the large Daphnia we can suppose that the size range of prey offered was appropriate for juveniles but too small for adults. Thus, young instars are likely to have greater facility in capturing small prey than adults.

Our results support the hypothesis of size selective predation, since both adults and juveniles preyed more on the large-sized Daphnia than on the medium-sized Ceriodaphnia. The size of zooplankton prey is considered a key factor in the preference of predators in lentic ecosystems (Zaret, 1980; Brooks and Dodson, 1965). This idea has led to the generalization that some aquatic invertebrates are size selective predators. In accordance, Scott and Murdoch (1983), Murdoch and Scott (1984) and Gilbert and Burns (1999) observed that the heteropteran notonectids select prey by size, with a strong preference for the largest zooplankton species. Blaustein (1998) showed that Notonecta maculata Fabricius structured a zooplankton community by size selective predation, resulting in reduction of the density of larger species, without affecting the density of smaller ones, such as Ceriodaphnia sp. In this study, the exception occurred in the experiment with the small-sized B. tubicen, where predators presented the highest ingestion rate. But in this specific case, the results were biased by the prey behavior of agglomerating at the water surface, which facilitates predation. The two other cladocerans do not behave as Bosmina, but they must rise up to the water surface to be captured by gerrids. Since gerrids possess a well developed visual system, with relatively large eyes, vision and water vibration seem to be sufficient to trigger an attack. The lack of predation of $C$. richardi by adult gerrid was possibly owing to the smaller prey size and not to problems of detection.

The hypothesis that higher population densities of gerrids would be found in the littoral zone of Lake Monte Alegre was confirmed. A few studies have shown that gerrids tend to occupy the littoral zone, where aquatic vegetation can be abundant (Spence, 1981; Nummelin et al., 1984). Macrophytes are probably a key factor influencing the distribution of this species of gerrid, since they are preferentially distributed at their edge in the lake. Rubenstein (1984) showed that the gerrid Gerris remigis Say remains in microhabitats with better food quality and, consequently, better reproductive capacity. In macrophyte stands of the lake, a wide variety of microhabitats can be found, that contribute to a greater diversity of invertebrates (Meschiatti and Arcifa, 2002; Cleto-Filho and Arcifa,
2006), including planktonic cladocerans and copepods (Souza, 2015). Terrestrial invertebrates are also abundant in macrophytes, such as insects that eventually fall on the water, becoming vulnerable to predation (Domingos, 2012 - personal observation). Shelter is another factor that influences gerrid preference by the littoral. In experiments, all species of gerrids showed habitat preference, avoiding those with low coverage, which are more influenced by wind and wave disturbance (Spence, 1981). Macrophytes can also provide shelter against predators, as shown by Cook and Streams (1984). They demonstrated in laboratory experiments, with Lepomis sp. as predator and notonectids as prey, that the presence of vegetation increases the search time of the notonectid by the fish, decreasing its capture success. However, predation on gerrids can be low due to secretions produced by the metathoracic scent glands, which make them distasteful to predators (Andersen and Polhemus, 1976). Accordingly, these insects are not a dietary item of fish species that share the same environment in Lake Monte Alegre (Meschiatti and Arcifa, 2002). Furthermore, macrophytes are a suitable oviposition site, since leaves and other plant structures are suitable for females to lay eggs, what is crucial because it can influence the survival of younger individuals against predation by older instars and another predators (Haskins, 1997). Aggregated distribution may result from the preference for certain sites for oviposition or shelter, where prey are more abundant or competition by food and space resources with other species is lower (Foster and Treherne, 1980).

Our results do not support the hypothesis that the fluctuations of the gerrid population were related to abiotic factors. As the population fluctuations were irregular throughout seasons in the lake, they were apparently not related with the abiotic factors, such as temperature, wind, and rainfall. In a study of population dynamics carried out in a whole season period, Jamieson (1973) observed differences in the timing of gerrid life cycle, which apparently separated the peaks of abundance of several species. In this study, the highest densities in the warm season, with a progressive increase from late January to April, coincided with the rise in primary productivity in the lake (Ferreira, 2013), and density decreases were probably related to the reproductive cycle of the $R$. crassifemur. Gerrids of tropical regions reproduce throughout the year (Cheng, 1966). Our results showed similar results, since all instars were found almost during all the study period, except from September to November when abundances were low and some instars were absent. A hypothesis that deserves to be further explored is that gerrids and notonectids avoid competition by lower temporal overlap. Both insects share similar ecological niches, but higher densities of the notonectid M. uruguayensis in the cool season (Domingos and Arcifa, In press), coincided with lower densities of gerrids.

\subsection{Final remarks}

In conclusion, this study contributed to enlarge the knowledge of invertebrate predation on the zooplankton community of tropical shallow lakes and on the ecology 
of gerrids. Due to the preferential distribution of the gerrid population in the littoral zone, predation pressure would be greater on prey that are littoral inhabitants. Planktonic microcrustaceans prefer, in general, the limnetic zone, but can also be found in the littoral zone (Souza, 2015). However, larger cladocerans use less often the littoral as shelter against predation, because predation by fish, notonectids, and gerrids (Arcifa et al., In press; Domingos and Arcifa, In press; this study) is stronger in that zone.

In laboratory experiments with predators and prey of the lake, the maximum ingestion rates of $0.5 \mathrm{prey} / \mathrm{h}$ by Chaoborus (Castilho-Noll and Arcifa, 2007a), $1.2 \mathrm{prey} / \mathrm{h}$ by notonectid (Domingos and Arcifa, In press) are lower or similar to that of the gerrid (1.3 prey/h; this study). However, as the gerrid moves over the water surface, inserting only its sucking apparatus in the water, only cladocerans that reach the surface film are preyed on. The other invertebrates in Lake Monte Alegre, such as chaoborid larvae, which are more abundant in the limnetic zone (Arcifa et al., 2013; In press) and the notonectid, which is able to dive into shallow waters, are probably more efficient predators than the gerrid Rheumatobates crassifemur.

\section{Acknowledgements}

This research was carried out at the Laboratory of Limnology, Biology Department of FFCLRP - University of São Paulo. We are grateful to RW Silva for help in the field, to AL Melo who kindly identified the gerrid species, to the PhD students TCS Ferreira, BB Souza and FT Mise for discussion and ideas, and CAPES for a grant to AR Domingos. We also thank three anonymous reviewers for valuable suggestions.

\section{References}

ANDERSEN, N.M. and POLHEMUS, J.T., 1976. Water-striders (Hemiptera: Gerridae, Veliidae, etc.). In: L. CHENG, ed. Marine insects. Amsterdam: Elsevier.

ANDERSEN, N.M., 1982. The semiaquatic bugs (Hemiptera: Gerromorpha) phylogeny, adaptations, biogeography and classification. Entomonograph, vol. 3, pp. 1-455.

ARCIFA, M.S. and MESCHIATTI, A.J., 1993. Distribution and feeding ecology of fishes in a Brazilian reservoir: Lake Monte Alegre. Interciencia, vol. 18, no. 6, pp. 83-87.

ARCIFA, M.S., 2000. Feeding habits of Chaoboridae larvae in a tropical Brazilian reservoir. Brazilian Journal of Biology $=$ Revista Brasileira de Biologia, vol. 60, no. 4, pp. 591-597. http://dx.doi. org/10.1590/S0034-71082000000400008.

ARCIFA, M.S., BUNIOTO, T.C., PERTICARRARI, A. and MINTO, W.J., 2013. Diel horizontal distribution of microcrustaceans and predators throughout a year in a shallow neotropical lake. Brazilian Journal of Biology $=$ Revista Brasileira de Biologia, vol. 73, no. 1, pp. 103-114. http://dx.doi.org/10.1590/S151969842013000100012. PMid:23644793.

ARCIFA, M.S., FERREIRA, T.C.S., FILETO, C., CASTILHONOLL, M.S.M., BUNIOTO, T.C. and MINTO, W.J., 2015. A long-term study on crustacean plankton of a shallow tropical lake: the role of invertebrate predation. Journal of Limnology, vol. 74 , no. 3, pp. 606-617.

ARCIFA, M.S., GOMES, E.A.T. and MESCHIATTI, A.J., 1992. Composition and fluctuations of the zooplankton of a tropical Brazilian reservoir. Archiv für Hydrobiologie, vol. 123, no. 4, pp. 479-495.

ARCIFA, M.S., MESCHIATTI, A.J. and GOMES, E.A.T., 1990. Thermal regime and stability of a tropical shallow reservoir: Lake Monte Alegre, Brazil. Revue d'Hydrobiologie tropicale, vol. 23, no. 4, pp. 271-281.

ARCIFA, M.S., PERTICARRARI, A., BUNIOTO, T.C., DOMINGOS, A.R. and MINTO, W.J., In press. Microcrustaceans and predators: diel migration in a tropical lake and comparison with shallow warm lakes. Limnetica.

ARNÉR, M., KOIVISTO, S., NORBERG, J. and KAUTSKY, N., 1998. Trophic interactions in rockpool food webs: regulation of zooplankton and phytoplankton by Notonecta and Daphnia. Freshwater Biology, vol. 39, no. 1, pp. 79-90. http://dx.doi. org/10.1046/j.1365-2427.1998.00262.x.

BAILEY, P.C.E., 1987. Abundance and age-specific spatial and temporal distribution in two waterbug species, Anisops deanei (Notonectidae) and Ranatra dispar (Nepidae) in three farm dams in south Australia. Oikos, vol. 49, no. 1, pp. 83-90. http://dx.doi. org/10.2307/3565557.

BLAUSTEIN, L., 1998. Influence of the predatory backswimmer, Notonecta maculata, on invertebrate community structure. Ecological Entomology, vol. 23, no. 3, pp. 246-252. http://dx.doi. org/10.1046/j.1365-2311.1998.00138.x.

BROOKS, J.L. and DODSON, S.I., 1965. Predation, body size, and composition of plankton. Science, vol. 150, no. 3692, pp. 28-35. http://dx.doi.org/10.1126/science.150.3692.28. PMid:17829740.

BROOKS, J.L., 1968. The effects of prey size selection by lake planktivores. Systematic Biology, vol. 17, no. 3, pp. 273-291. http://dx.doi.org/10.1093/sysbio/17.3.273.

CALABRESE, D.M., 1977. The habitats of Gerris F. (Hemiptera: Heteroptera: Gerridae) in Connecticut. Annals of the Entomological Society of America, vol. 70, no. 6, pp. 977-983. http://dx.doi. org/10.1093/aesa/70.6.977.

CASSANO, C.R., CASTILHO-NOLL, M.S.M. and ARCIFA, M.S., 2002. Water mite predation on zooplankton of a tropical lake. Brazilian Journal of Biology $=$ Revista Brasileira de Biologia, vol. 62, no. 4A, pp. 565-571. http://dx.doi.org/10.1590/S151969842002000400002. PMid:12659004.

CASTILHO-NOLL, M.S.M. and ARCIFA, M.S., 2007a. Chaoborus diet in a tropical lake and predation of microcrustaceans in laboratory experiments. Acta Limnologica Brasiliensia, vol. 19, no. 2, pp. 163-174.

CASTILHO-NOLL, M.S.M and ARCIFA, M.S., 2007b. Mesocosm experiment on the impact of invertebrate predation on zooplankton of a tropical lake. Aquatic Ecology, vol. 41, no. 4, pp. 587-598. http://dx.doi.org/10.1007/s10452-007-9112-4.

CHENG, L., 1966. Studies on the biology of the Gerridae. II. The life history of Metrocoris tenuicornis Esaki. Entomologist's Monthly Magazine, vol. 102, pp. 273-282.

CHENG, L., 1974. Notes on the ecology of the oceanic insects Holobates. Marine Fisheries Review, vol. 36, no. 2, pp. 1-7. 
CHENG, L., 1985. Biology of Halobates (Heteroptera: Gerridae). Annual Review of Entomology, vol. 30, no. 1, pp. 111-135. http:// dx.doi.org/10.1146/annurev.en.30.010185.000551.

CLAESSEN, D., DE ROOS, A.M. and PERSSON, L., 2000. Dwarfs and giants: cannibalism and competition in size-structured populations. American Naturalist, vol. 155, no. 2, pp. 219-237. http://dx.doi.org/10.1086/303315. PMid:10686162.

CLETO-FILHO, S.E.N. and ARCIFA, M.S., 2006. Horizontal distribution and temporal variation of the zoobenthos of a tropical Brazilian lake. Acta Limnologica Brasiliensia, vol. 18, no. 4, pp. 407-421.

COHEN, J.E., PIMM, S.L., YODZIS, P. and SALDANA, J., 1993. Body sizes of animal predators and animal prey in food webs. Journal of Animal Ecology, vol. 62, no. 1, pp. 67-78. http:// dx.doi.org/10.2307/5483.

COOK, W.L. and STREAMS, F.A., 1984. Fish predation on Notonecta (Hemiptera): relationship between prey risk and habitat utilization. Oecologia, vol. 64, no. 2, pp. 177-183. http://dx.doi. org/10.1007/BF00376868.

COOPER, S.D., 1983. Selective predation on cladocerans by common pond insects. Canadian Journal of Zoology, vol. 61, no. 4, pp. 879-886. http://dx.doi.org/10.1139/z83-115.

CUMMINS, K.W., 1973. Trophic relations of aquatic insects. Annual Review of Entomology, vol. 18, no. 1, pp. 183-206. http:// dx.doi.org/10.1146/annurev.en.18.010173.001151.

DOMINGOS, A.R. and ARCIFA, M.S., In press. Distribution and fluctuations of backswimmers (Notonectidae) in a tropical shallow lake and predation on microcrustaceans. Brazilian Journal of Biology $=$ Revista Brasileira de Biologia

EITAM, A. and BLAUSTEIN, L., 2010. Effects of predator density and duration of predator occupancy on crustacean abundance and diversity in experimental pools. Hydrobiologia, vol. 652, no. 1, pp. 269-276. http://dx.doi.org/10.1007/s10750-010-0357-x.

FERREIRA, T.C.S., 2013. Competição, predação e variação temporal de microcrustáceos planctônicos no Lago Monte Alegre. Ribeirão Preto: Universidade de São Paulo, 86 p. Master Thesis.

FOSTER, W.A. and TREHERNE, J.E., 1980. Feeding, predation and aggregation behaviour in a marine insect, Halobates robustus Barber (Hemiptera: Gerridae), in the Galapagos Islands. Proceedings of the Royal Society of London. Series B, Biological Sciences, vol. 209, no. 1177, pp. 539-553. http://dx.doi.org/10.1098/ rspb.1980.0111.

GERGS, A. and RATTE, H.T., 2009. Predicting functional response and size selectivity of juvenile Notonecta maculata foraging on Daphnia magna. Ecological Modelling, vol. 220, no. 23, pp. 3331-3341. http://dx.doi.org/10.1016/j.ecolmodel.2009.08.012.

GILBERT, J.J. and BURNS, C.W., 1999. Some observations on the diet of the backswimmer, Anisops wakefieldi (Hemiptera: Notonectidae). Hydrobiologia, vol. 412, pp. 111-118. http:// dx.doi.org/10.1023/A:1003812718853.

HALL, D.J., COOPER, W.E. and WERNER, E.E., 1970. An experimental approach to the production dynamics and structure of freshwater animal communities. Limnology and Oceanography, vol. 15, no. 6, pp. 839-928. http://dx.doi.org/10.4319/lo.1970.15.6.0839.

HALL, D.J., THRELKELD, S.T., BURNS, C.W. and CROWLEY, P.H., 1976. The size-efficiency hypothesis and the size structure of zooplankton communities. Annual Review of Ecology and
Systematics, vol. 7, no. 1, pp. 177-208. http://dx.doi.org/10.1146/ annurev.es.07.110176.001141.

HANAZATO, T. and YASUNO, M., 1989. Zooplankton community structure driven by vertebrate and invertebrate predators. Oecologia, vol. 81, no. 4, pp. 450-458. http://dx.doi.org/10.1007/BF00378951.

HASKINS, K.E., 1997. Oviposition site preferences and spatial segregation in two species of stream-dwelling waterstriders (Hemiptera: Gerridae). American Midland Naturalist, vol. 137, no. 2, pp. 404-407. http://dx.doi.org/10.2307/2426861.

JAMIESON, G.S., 1973. Coexistence in the Gerridae. Vancouver: University of British Columbia, 255 p. PhD Thesis.

KERFOOT, W.C. and SIH, A.E.D.S., 1987. Predation: direct and indirect impacts on aquatic communities. Hanover: University Press of New England. 386 p.

MCLEAN, E.B., 1990. Sexual dimorphism and predaceous feeding habits of the waterstrider Gerris remigis Say (Heteroptera: Gerridae). Canadian Journal of Zoology, vol. 68, no. 12, pp. 2688-2691. http://dx.doi.org/10.1139/z90-371.

MESCHIATTI, A.J. and ARCIFA, M.S., 2002. Early life stages of fish and the relationships with zooplankton in a tropical reservoir. Brazilian Journal of Biology $=$ Revista Brasileira de Biologia, vol. 62, no. 1, pp. 41-50. http://dx.doi.org/10.1590/ S1519-69842002000100006. PMid:12185922.

MURDOCH, W.W. and SCOTT, M.A., 1984. Stability and extinction of laboratory populations of zooplankton preyed on by the backswimmer Notonecta. Ecology, vol. 64, no. 4, pp. 1231-1248. http://dx.doi.org/10.2307/1938330.

MURDOCH, W.W., SCOTT, M.A. and EBSWORTH, P., 1984. Effects of the general predator, Notonecta (Hemiptera) upon a freshwater community. Journal of Animal Ecology, vol. 53, no. 3, pp. 791-808. http://dx.doi.org/10.2307/4660.

NUMMELIN, M., 1989. Cannibalism in waterstriders (Heteroptera: Gerridae): is there kin recognition? Oikos, vol. 56, no. 1, pp. 8790. http://dx.doi.org/10.2307/3566090.

NUMMELIN, M., VEPSÄLÄINEN, K., SPENCE, J.R. and VEPSALAINEN, K., 1984. Habitat partitioning among developmental stages of waterstriders (Heteroptera: Gerridae). Oikos, vol. 42, no. 3, pp. 267-275. http://dx.doi.org/10.2307/3544394.

PECKARSKY, B.L., 1982. Aquatic insect predator-prey relations. Bioscience, vol. 32, no. 4, pp. 261-266. http://dx.doi. org/10.2307/1308532.

RUBENSTEIN, D.I., 1984. Resource acquisition and alternative mating strategies in water striders. Integrative and Comparative Biology, vol. 24, no. 2, pp. 345-353.

SCOTT, M.A. and MURDOCH, W.W., 1983. Selective predation by the backswimmer, Notonecta. Limnology and Oceanography, vol. 28, no. 2, pp. 352-366. http://dx.doi.org/10.4319/lo.1983.28.2.0352.

SOUZA, B.B., 2015. Variação espacial e temporal de microcrustáceos planctônicos do lago Monte Alegre e experimentos abordando a influência da qualidade do alimento sobre o desempenho dos cladóceros. Ribeirão Preto: Universidade de São Paulo, 80 p. Masters Thesis.

SPENCE, J.R. and ANDERSON, N.M., 1994. Biology of water striders: interactions between systematics and ecology. Annual Review of Entomology, vol. 39, no. 1, pp. 101-128. http://dx.doi. org/10.1146/annurev.en.39.010194.000533. 
SPENCE, J.R. and SCUDDER, G.G.E., 1980. Habitats, life cycles, and guild structure among water striders (Heteroptera: Gerridae) on the Fraser Plateau of British Columbia. Canadian Entomologist, vol. 112, no. 8, pp. 779-792. http://dx.doi.org/10.4039/Ent112779-8.

SPENCE, J.R., 1981. Experimental analysis of microhabitat selection in water-striders (Heteroptera: Gerridae). Ecology, vol. 62, no. 6, pp. 1550-1514. http://dx.doi.org/10.2307/1941507.

VEPSÄLÄINEN, K., 1973. The distribution and habitats of Gerris Fabr. species (Heteroptera, Gerridae) in Finland. Annales Zoologici Fennici, vol. 10, pp. 419-444.

WARREN, P.H. and LAWTON, J.H., 1987. Invertebrate predatorprey body size relationships: an explanation for upper triangular food webs and patterns in food web structure? Oecologia, vol. 74, no. 2, pp. 231-235. http://dx.doi.org/10.1007/BF00379364.
WHEELWRIGHT, N.T. and WILKINSON, G.S., 1985. Space use by a Neotropical water strider (Hemiptera: Gerridae): sex and age-class difference. Biotropica, vol. 17, no. 2, pp. 165-169. http://dx.doi.org/10.2307/2388509.

WOODWARD, G. and HILDREW, A.G., 2002. Body-size determinants of niche overlap and intraguild predation within a complex food web. Journal of Animal Ecology, vol. 71, no. 6, pp. 1063-1074. http://dx.doi.org/10.1046/j.1365-2656.2002.00669.x.

WOODWARD, G., EBENMAN, B., EMMERSON, M., MONTOYA, J.M., OLESEN, J.M., VALIDO, A. and WARREN, P.H., 2005. Body size in ecological networks. Trends in Ecology \& Evolution, vol. 20, no. 7, pp. 402-409. http://dx.doi.org/10.1016/j. tree.2005.04.005. PMid:16701403.

ZARET, T.M., 1980. Predation and freshwater communities. New Haven: Yale University Press. 187 p. 